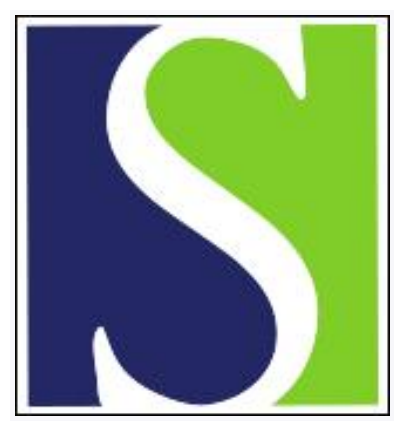

Scand J Work Environ Health 1989;15(1):24-29

https://doi.org/10.5271/sjweh.1886

Issue date: Feb 1989

\title{
Cancer risks among New Zealand meat workers.
}

by Reif JS, Pearce NE, Fraser J

Affiliation: Department of Environmental Health, College of Veterinary Medicine and Biomedical Sciences, Fort Collins, Colorado.

This article in PubMed: www.ncbi.nlm.nih.gov/pubmed/2922585 


\title{
Cancer risks among New Zealand meat workers
}

\author{
by John S Reif, DVM, ${ }^{1}$ Neil E Pearce, PhD, ${ }^{2}$ James Fraser, $\mathrm{MS}^{3}$
}

\begin{abstract}
REIF JS, PEARCE NE, FRASER J. Cancer risks among New Zealand meat workers. Scand $J$ Work Environ Health 1989;15:24-29. The study reports a series of case-referent studies based on the New Zealand Cancer Register and involving 19904 male cancer patients aged 20 years or more at the time of registration during the period 1980-1984. For each cancer site, the registrations for the remaining sites formed the reference group. An increased risk for lung (OR 1.30, $95 \%$ CI 1.06-1.58) and laryngeal (OR 2.01, $95 \%$ CI 1.19-3.39) cancer was found among meatworkers. It was confined to men aged $<65$ years at registration. The risk for soft-tissue sarcoma was elevated (OR $1.90,95 \% \mathrm{CI} 0.90-4.02)$. The risk estimate for all types of leukemia was elevated moderately (OR $1.45,95 \% \mathrm{CI} 0.90-2.31$ ), but cell typespecific analyses revealed a greater effect for acute myeloid leukemia (OR 2.12, 95 \% CI 1.09-4.12). This study adds to the evidence that employment as a meatworker is associated with increased risk for several forms of cancer.
\end{abstract}

Key terms: abattoir workers, acute myeloid leukemia, lung cancer, occupational exposures, slaughterhouse workers, soft-tissue sarcoma.

Recent studies in New Zealand (1-6), the United States $(7,8)$, and several European countries $(9-13)$ have focused attention on meatworkers as an occupational group that appears to be at increased risk for several forms of cancer. Slaughterhouse workers, meat processors, packers, and butchers are exposed to substances that are carcinogenic in animals or suspected to be carcinogenic in humans. The chlorophenol 2,4,6-trichlorophenol $(2,4,6-\mathrm{TCP})$ has been used in the treatment of pelts in New Zealand slaughterhouses (1). Other chemicals found in meat packing plants include nitrosamines, butylated hydroxyanisole (BHA), and butylated hydroxytoluene $(\mathrm{BHT})(7,14,15)$. In addition to chemical carcinogens, meatworkers may be exposed to oncogenic retroviruses such as the bovine leukemia virus (BLV), which causes lymphosarcoma in cattle (16) and is present in tissues and milk of infected animals (17). Despite these exposures, only limited information exists to assess the risk of cancer among persons employed as meatworkers.

Increased risks among meatworkers have been described in studies of soft-tissue sarcoma $(1,2)$, nonHodgkin's lymphoma (NHL) $(3,5)$, and acute myeloid leukemia (4) in New Zealand. These previous casereferent studies included registrants with soft-tissue sarcoma from 1976 to $1982(1,2)$, non-Hodgkin's lymphoma from 1977 to $1981(3,5)$, and leukemia from

1 Department of Environmental Health, College of Veterinary Medicine and Biomedical Sciences, Fort Collins, Colorado, United States.

2 Department of Community Health, Wellington School of Medicine, Wellington, New Zealand.

${ }^{3}$ National Health Statistics Centre, Wellington, New Zealand.

Reprint requests to: Dr JS Reif, Department of Environmental Health, Colorado State University, Fort Collins, CO 80523, USA.
1979 to 1983 (4). Lung, bone, oral, and pharyngeal cancer and Hodgkin's disease were associated with meat work in a historical cohort study in the United States (7).

Increased risks for lung cancer in butchers and slaughterhouse meatcutters have been reported from several European countries over varying time periods (9-13).

Cancer risks among meatworkers may be effectively studied in New Zealand due to its large meat export industry and the existence of a national cancer register. We undertook the current investigation in order to assess further the increased risks for lymphatic and hematopoietic cancer and soft-tissue sarcoma noted among meatworkers in previous studies and to determine whether the risk for lung cancer reported elsewhere also occurred in New Zealand. Furthermore, it seemed appropriate to determine whether this occupational group experienced excess risks for other relevant cancer sites. Therefore, the current study constitutes an analysis of risks across all cancer sites among New Zealand meatworkers.

\section{Subjects and methods}

Cancer cases reported for adult men in the period 1980 to 1984 were obtained from the national cancer register. The New Zealand Cancer Register obtains complete population coverage from public and private hospitals throughout the country, as well as from death certificates and autopsy findings (18). Nearly all patients who die of cancer have been reported to the national cancer register prior to death. The data file included all 24762 men aged 20 years or more at the time of registration. Analysis was restricted to the 19904 men who had a recorded occupation, $80 \%$ of the total sample (table 1). 
The study design involved a series of case-referent studies, each based on the overall group of 19904 cancer registrants. For each site, the registrants for other sites formed the reference group. This study design has been used in several previous investigations based on the National Cancer Register of New Zealand, and the relevant issues have been described in two recent papers $(19,20)$. The main advantage of using persons with other cancers as referents is the minimization of information bias, as well as the minimization of selection bias since cancer registration is virtually complete (18). The main potential disadvantage is that selection bias may occur if the exposure under study is associated with an increased risk for other cancer sites. Any such bias is generally likely to be small in occupational studies (19), although more significant bias may occur if an exposure is associated with a common cancer such as lung cancer. Even in this situation, the appropriate approach is not always clear, since excluding exposure-related cancers from the reference group may actually increase the net bias (20).

In this instance a check on the potential for selection bias was provided by New Zealand cancer mortality data for food and beverage workers (the general occupational category to which meatworkers belong). The overall age-standardized cancer mortality for food and beverage workers was 161 per 100000 person-years at risk, as compared to 139 per 100000 person-years at risk for all employed men. The excess mortality was due almost entirely to an excess for lung cancer, and the overall mortality for other cancers in food and beverage workers was virtually the same as that for other employed men. This information, together with the finding in the current study of an excess risk for lung cancer, but not for other major cancer sites, suggested that lung cancer should be excluded from the reference group.

Thus the 4224 cases of lung cancer were excluded from the analyses of other sites. For example, in the analysis of the data for cancer of the buccal cavity [International Classification of Diseases (ICD) codes 140-149], the case group consisted of the 698 registrants with this cancer type, and the reference group comprised the other 14982 cancer registrants for sites other than lung cancer. A similar procedure was followed for the other cancer sites, except for the calculation of risk for subtypes of leukemia, for which other forms of leukemia were also excluded from the referents. For lung cancer, all other cases of cancer $(\mathrm{N}=$ 15680 ) were included as referents.

Occupation was defined in the National Cancer Register as the individual's current or most recent occupation at the time of registration and was coded with the use of the New Zealand Standard Classification of Occupations (NZSCO) (21), a modification of the International Standard Classification of Occupations (22). Occupational information for cancer registrants is obtained mainly by interview at the time of hospitali- zation. The NZSCO category of butchers and meat preparers included slaughtermen, other slaughterhouse workers, freezing workers (employed in large packing plants preparing frozen meat for export), meat graders, and retail butchers. It did not include tanners, fellmongers (workers who remove wool from sheep carcasses), and pelt dressers.

Analyses were conducted with the statistical analysis system (SAS) (23). The odds ratios (OR) were estimated with the Mantel-Haenszel procedure (23), and the $95 \%$ confidence intervals $(95 \% \mathrm{CI})$ were calculated with Miettinen's approximate method (25). All the analyses were adjusted for age in 10-year intervals.

\section{Results}

The age-adjusted odds ratios for specific cancer sites are shown in table 2 . An excess risk among meatworkers was observed for two forms of respiratory tract cancer, ie, malignant neoplasms of the lung and larynx. Other smoking-related sites did not show consistently elevated risks. For example, an increase was noted for cancer of the esophagus (OR 1.38) and pancreas (OR 1.45), but the odds ratios for bladder cancer (OR 0.70 ), cancer of the oral cavity (OR 0.66 ), and cancer of the pharynx (OR 1.07) were not elevated. The precision of these estimates was poor. There were no cases of cancer of the nasal cavity and sinuses or pleura among the meatworkers.

The finding of an odds ratio of $1.90(95 \% \mathrm{Cl} 0.90-$ 4.02) for soft-tissue sarcoma, based on seven exposed

Table 1. Cases of cancer in men aged 20 years or more by site - New Zealand Cancer Register, 1980-1984.

\begin{tabular}{|c|c|c|c|}
\hline \multirow[t]{2}{*}{ Type of cancera } & \multicolumn{2}{|c|}{$\begin{array}{l}\text { Cases with } \\
\text { occupation } \\
\text { recorded }\end{array}$} & \multirow{2}{*}{$\begin{array}{c}\text { Total } \\
\text { number } \\
\text { of cases }\end{array}$} \\
\hline & $\mathrm{N}$ & $\%$ & \\
\hline Buccal cavity $(140-49)$ & 698 & 75 & 932 \\
\hline Esophagus (150) & 385 & 83 & 463 \\
\hline Stomach (151) & 1014 & 81 & 1258 \\
\hline Colon (153) & 2043 & 82 & 2500 \\
\hline Rectum (154) & 1376 & 82 & 1679 \\
\hline Liver (155) & 184 & 83 & 223 \\
\hline Gallbladder (156) & 120 & 87 & 138 \\
\hline Pancreas (157) & 571 & 82 & 695 \\
\hline Larynx (161) & 303 & 82 & 379 \\
\hline Lung (162) & 4224 & 84 & 5031 \\
\hline Bone (170) & 49 & 83 & 59 \\
\hline Connective tissue (171) & 142 & 83 & 171 \\
\hline Malignant melanoma (172) & 1116 & 77 & 1448 \\
\hline Prostate (185) & 2435 & 73 & 3340 \\
\hline Testis (186) & 399 & 92 & 435 \\
\hline Bladder (188) & 912 & 72 & 1259 \\
\hline Kidney/other urinary $(189)$ & 542 & 81 & 666 \\
\hline Brain, nervous system $(191,192)$ & 452 & 89 & 506 \\
\hline Hodgkin's disease (201) & 170 & 91 & 186 \\
\hline Non-Hodgkin's lymphoma $(200,202)$ & 535 & 82 & 652 \\
\hline Multiple myeloma (203) & 295 & 83 & 355 \\
\hline Leukemia $(204-208)$ & 534 & 82 & 649 \\
\hline Other & 1405 & 81 & 1738 \\
\hline Total $(140-208)$ & 19904 & 80 & 24762 \\
\hline
\end{tabular}

a Code of the International Classification of Diseases, ninth revision, in parentheses. 
cases, was consistent with the previously described association of soft-tissue sarcoma with meat work in New Zealand $(1,2)$. However, the association between nonHodgkin's lymphoma and meat work described in two previous New Zealand case-referent studies $(3,5)$ was not seen in the current analysis. The overall odds ra-

Table 2. Age-adjusted odds ratios and $95 \%$ confidence intervals $(95 \% \mathrm{Cl})$ for cancer in male meatworkers by site - New Zealand Cancer Register 1980-1984.

\begin{tabular}{lrcr}
\hline Type of cancer & $\begin{array}{c}\text { Exposed } \\
\text { cases }\end{array}$ & $\begin{array}{c}\text { Odds } \\
\text { ratio }\end{array}$ & $95 \% \mathrm{Cl}$ \\
\hline Buccal cavity & 15 & 0.80 & $0.48-1.35$ \\
Esophagus & 13 & 1.38 & $0.79-2.41$ \\
Stomach & 31 & 1.26 & $0.87-1.83$ \\
Colon & 48 & 0.92 & $0.68-1.25$ \\
Rectum & 28 & 0.78 & $0.53-1.15$ \\
Liver & 8 & 1.72 & $0.85-3.49$ \\
Gallbladder & 1 & 0.33 & $0.05-2.16$ \\
Pancreas & 20 & 1.45 & $0.92-2.29$ \\
Larynx & 15 & 2.01 & $1.19-3.39$ \\
Lung & 135 & 1.30 & $1.06-1.58$ \\
Bone & 3 & 2.34 & $0.74-7.35$ \\
Connective tissue & 7 & 1.90 & $0.90-4.02$ \\
Malignant melanoma & 23 & 0.70 & $0.45-1.09$ \\
Prostate & 52 & 0.91 & $0.67-1.22$ \\
Testis & 11 & 0.89 & $0.47-1.67$ \\
Bladder & 16 & 0.70 & $0.42-1.15$ \\
Kidneylother urinary & 16 & 1.16 & $0.70-1.92$ \\
Brain, nervous system & 11 & 0.87 & $0.47-1.60$ \\
Hodgkin's disease & 5 & 1.03 & $0.42-2.55$ \\
Non-Hodgkin's lymphoma & 12 & 0.85 & $0.48-1.52$ \\
Multiple myeloma & 7 & 0.96 & $0.45-2.04$ \\
Leukemia & 19 & 1.45 & $0.90-2.31$ \\
Other & 37 & 1.05 & $0.74-1.48$ \\
\hline Total & 533 & $\cdot$ & \\
\hline & & & \\
\hline
\end{tabular}

tio for non-Hodgkin's lymphoma was not elevated, nor were those for the various subtypes of non-Hodgkin's lymphoma including lymphosarcoma and reticulosarcoma (ICD 200) (OR 0.81), or other forms (ICD 202) (OR 0.90).

The estimate of risk for all types of leukemia was elevated (OR 1.45), although the estimate was imprecise. In cell type-specific analyses (table 3 ), the previous finding (4) of an elevated risk for acute myeloid leukemia (OR 2.12) was reproduced, although it should be emphasized that there was considerable overlap with the previous study. The risk for chronic myeloid leukemia was similar (OR 2.12) to that for acute myeloid leukemia, but the precision of the estimate was lower due to smaller numbers. Similarly, an apparent excess of meatworkers among cases of acute lymphocytic leukemia (OR 2.54) was found but was based on only three exposed cases.

We examined the relationship between an increased risk for cancer among meatworkers and age by separating the cases and referents into those aged 65 years and over and those less than 65 years of age at the time of registration (table 4). For cancers of the larynx and lung, the excess risk was confined to the younger age group. The highest risks were noted for those less than 40 years of age for both cancers, ie, lung (OR 2.94, $95 \%$ CI 0.72-12.02) and larynx (OR 7.07, $95 \%$ CI 1.05-47.84). Similarly, among the subtypes of leukemia, the odds ratios tended to be greater for the younger men, although the estimates were based upon very small numbers of cases, and the odds ratios were also elevated for the older age groups.

Table 3. Age-adjusted odds ratios and $95 \%$ confidence intervals $(95 \% \mathrm{Cl})$ for leukemia in male meatworkers by subtype New Zealand Cancer Register, 1980-1984.

\begin{tabular}{|c|c|c|c|c|}
\hline Type of cancer ${ }^{a}$ & $\begin{array}{l}\text { Number } \\
\text { of cases }\end{array}$ & $\begin{array}{l}\text { Exposed } \\
\text { cases }\end{array}$ & $\begin{array}{l}\text { Odds } \\
\text { ratio }\end{array}$ & $95 \% \mathrm{Cl}$ \\
\hline Acute lymphatic leukemia (204.0) & 47 & 3 & 2.54 & $0.81-7.95$ \\
\hline Chronic lymphatic leukemia (204.1) & 165 & 2 & 0.50 & $0.13-1.98$ \\
\hline Other lymphatic leukemia (204.2-.9) & 6 & 0 & $\cdot$ & . \\
\hline Acute myeloid leukemia (205.0) & 169 & 9 & 2.12 & $1.09-4.12$ \\
\hline Chronic myeloid leukemia (205.1) & 77 & 4 & 2.12 & $0.79-5.71$ \\
\hline Other myeloid leukemia $(205.2-9$ ) & 13 & 0 & 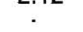 & . \\
\hline Other leukemia $(206-208)$ & 57 & 1 & 0.74 & $0.10-5.26$ \\
\hline
\end{tabular}

a Code of the International Classification of Diseases, ninth revision, in parentheses.

Table 4. Odds ratios and $95 \%$ confidence intervals $(95 \% \mathrm{Cl})$ for cancer of the lung and larynx and leukemia by age group and occupation as a meatworker.

\begin{tabular}{|c|c|c|c|c|c|c|}
\hline \multirow{3}{*}{ Type of cancer } & \multicolumn{6}{|c|}{ Age group } \\
\hline & \multicolumn{3}{|c|}{$20-64$ years } & \multicolumn{3}{|c|}{$\geq 65$ years } \\
\hline & $\begin{array}{c}\text { Exposed } \\
\text { cases }\end{array}$ & $\begin{array}{l}\text { Odds } \\
\text { ratio }\end{array}$ & $95 \% \mathrm{Cl}$ & $\begin{array}{l}\text { Exposed } \\
\text { cases }\end{array}$ & $\begin{array}{l}\text { Odds } \\
\text { ratio }\end{array}$ & $95 \% \mathrm{Cl}$ \\
\hline Larynx & 12 & 2.83 & $1.59-5.05$ & 3 & 0.92 & $0.29-2.95$ \\
\hline Lung & 80 & 1.64 & $1.26-2.15$ & 55 & 0.98 & $0.72-1.33$ \\
\hline Acute lymphatic leukemia & 2 & 2.14 & $0.51-9.03$ & 1 & 3.06 & $0.45-20.99$ \\
\hline Chronic lymphatic leukemia & 2 & 1.42 & $0.34-5.82$ & 0 & . & . \\
\hline Acute myeloid leukemia & 6 & 2.68 & $1.18-6.06$ & 3 & 1.55 & $0.49-4.91$ \\
\hline Chronic myeloid leukemia & 3 & 2.76 & $0.89-8.59$ & 1 & 1.22 & $0.17-8.90$ \\
\hline
\end{tabular}




\section{Discussion}

The finding of an excess risk for lung cancer among male meatworkers in New Zealand corroborates the excess of lung cancer among butchers and meatcutters in national mortality data for different time periods in Sweden (9), England and Wales (10), and Denmark (11) and in historical cohort studies of male (7) and female (8) meatworkers in the United States.

Johnson et al (7) noted that various plastics are used to wrap meats, eg, polystyrene, polyvinylidene, polyethylene, rubber hydrochloride, cellophane, and polyvinyl chloride (PVC). Exposure to fumes from the thermal decomposition of plastic film causes the acute syndrome known as "meat-wrapper's asthma" (26). When heat is used to cut and seal PVC during the wrapping or labeling processes, the decomposition products include benzene, phthalic anhydride, and phthalates $(7,27)$. Benzene is an established human leukemogen (28), while the phthalates have been reported to be carcinogenic in animals (29).

Exposures to fumes liberated during the packaging and labeling of meat or to nitrosamines, BHA, or BHT were suggested as candidates to explain the excesses of lung cancer found among the cohorts of male (7) and female (8) meatworkers in Baltimore, Maryland. In the studies from the United States, the excess risks among male workers were found in packing plants rather than slaughterhouses. The women were engaged primarily in the wrapping and labeling of meat in packing plants, grocery stores, or supermarkets (8). In a recent Swedish study (13), the type of work or work area was not related to the risk of lung cancer among butchers and slaughterhouse workers.

Unfortunately, a separation of these exposures in the New Zealand study was not possible, as the occupational category in the NZSCO combines slaughtermen, other slaughterhouse workers, meat graders and preparers, and retail butchers. However, New Zealand workers are engaged primarily in slaughtering, meatcutting, packing, and freezing meat for the export market, rather than in packaging for the domestic retail trade. Thus it would appear that only a minority of workers are exposed to PVC decomposition products.

The lung and laryngeal cancer findings are difficult to interpret because of the potential for confounding by tobacco smoking, which is the strongest determinant of these cancer types $(30,31)$. Smoking was found to be the predominant risk factor responsible for the increased incidence of lung cancer among butchers and meatworkers in a recent case-referent study in Sweden (13).

To evaluate the potential role of smoking in the excess risks found among meatworkers in New Zealand, we examined data on smoking and occupation from the 1981 census (32). Food and beverage workers, the occupational group to which meatworkers belong, were more likely to be current smokers $(46.8 \%)$ or ever smokers $(65.4 \%)$ than the total full-time male labor force, among which $37.7 \%$ smoked currently and $59.6 \%$ had ever smoked. The potential extent of confounding due to cigarette smoking was evaluated according to the method of Axelson (33). The odds ratios attributable to the relatively high smoking rates among meatworkers were estimated to be 1.20 for lung cancer and $\mathbf{1 . 1 6}$ for laryngeal cancer. Therefore, the increased risks for lung and laryngeal cancer found in the current study are likely to be due, at least in part, to cigarette smoking.

Slaughterhouse workers may be exposed to various chemicals, including 2,4,6-trichlorophenol (2,4,6-TCP) used in the treatment of pelts (34). This compound is highly skin permeable, and the treatment of pelts in New Zealand has involved manually removing the pelts from the treatment solutions and handling wet skins without protection. Studies with rats and mice have shown that 2,4,6-TCP can cause lymphomas, leukemias, and hepatocellular carcinoma (35). Epidemiologic studies in Sweden have found associations between exposure to chlorophenols and soft-tissue sarcoma $(36,37)$ and malignant lymphoma $(38)$, although previous New Zealand case-referent studies have not supported the association between chlorophenols and these cancers $(1,3,5)$. In particular, the findings for pelt department workers were similar to those for other slaughterhouse workers, and in only $22 \%$ of the cases among slaughterhouse workers did the person report working in pelt departments.

The failure to find an association between nonHodgkin's lymphoma and employment as a meatworker is in conflict with previous findings in New Zealand. A previous study (5) of 183 non-Hodgkin's lymphoma patients showed an association with employment as a meatworker, with similar estimates of risk (OR 1.8, 1.7) calculated for ICD 200 and 202. In the current analysis of 535 patients, odds ratios of 0.81 and 0.90 were calculated for the two categories of non-Hodgkin's lymphoma. An obvious difference between the studies is that the earlier study collected complete occupational histories by personal interview, while the present study used the current or most recent occupation recorded at the time of registration. Patients with other forms of cancer, obtained from the National Cancer Register, comprised the reference group for both comparisons.

Some increase in risk for leukemia among meatworkers was noted (OR 1.4), but it was more pronounced for specific cell types, particularly acute myeloid leukemia. The previously described association between acute myeloid leukemia and employment as a meatworker in New Zealand (4) was also found in the current analysis (OR 2.1), although there was considerable overlap of the two case groups. Recent evidence suggests that the acute nonlymphocytic leukemias are the most likely to be associated with occupational or environmental exposures (39). The association between leukemia and employment as a meat- 
worker is consistent with the frequently described increased risk among farmers (40) and suggests that common exposures may be involved.

The hypothesis that a leukemogenic agent is present in slaughterhouses is supported by the finding that veterinarians employed as meat inspectors also have an increased risk for lymphatic and hematopoietic cancers (41). Epidemiologic evidence for the role of zoonotic viruses in human cancer is currently weak, although some studies have found associations between various hematologic malignancies and farming (40). One candidate, bovine leukemia virus, is an exogenous $C$ type retrovirus which has been established as the etiologic agent of the adult form of bovine lymphosarcoma (16) and occurs in New Zealand (42). The virus is related closely to human $\mathrm{T}$-cell leukemia-lymphoma virus type 1 , the cause of adult T-cell leukemia in humans (43), and is transmitted horizontally (44). Virus particles are found in tissues and excretions of infected cows (16) and in milk (45). Erythroleukemia developed in two of six chimpanzees fed milk from cows infected with bovine leukemia virus (46), and chimpanzees inoculated with bovine leukemia virus became persistently infected (47). Bovine leukemia virus is capable of infecting human cells and inducing syncytia in tissue culture (48). Attempts to detect evidence of human infection with bovine leukemia virus by serologic methods have been generally unrewarding (49-52). However, the interpretation of serologic studies and attempts at identification of bovine leukemia virus in human cells remains inconclusive.

The major disadvantage of using register data for case-referent analyses of occupational cancer risks is the relatively crude nature of the exposure data. Occupational data are provided as the current or most recent employment at the time of registration rather than as a complete occupational history as might be obtained through an interview. Therefore, the estimation of risk for an ever-never exposure to meatwork is precluded. However, the net effect of this bias is in the conservative direction since the misclassification introduced will bias the estimate of risk towards the null value (53). More importantly, the data do not permit the examination of dose-response relationships based on duration of employment in an industry, the assessment of induction time, or the estimation of risks for specific departments or processes.

A potential disadvantage of using other cancers as the reference group may be the introduction of selection bias if the exposure being examined is associated with more than one form of cancer. In this instance the effect would be to reduce the estimate of relative risk. Conversely, some "other cancers" may be associated with other occupations and thus decrease the proportion of meatworkers in the reference group. The latter phenomenon would have the effect of artificially raising the estimate of relative risk. In this instance it was found that the age standardized cancer mortality rates for male food and beverage workers in New
Zealand were elevated and that this increase was due almost entirely to an increase in lung cancer mortality. Thus selection bias was minimized by the exclusion of lung cancers from the reference group. In any case, only minor changes in the odds ratio estimates occurred, depending on whether lung cancers were included or excluded from the reference group.

Despite the aforementioned limitations, and the possibility that the lung and laryngeal cancer findings may be due to smoking, this study adds to the growing body of evidence that employment as a meatworker is associated with several forms of cancer. Additional studies are needed to characterize the exposures which occur in various departments of the slaughterhouse and in the processing of meat products and to identify which chemical or viral carcinogens may be involved.

\section{Acknowledgments}

This study was conducted during the tenure of Dr Reif as Senior Fogarty International Fellow (1 FO6 TW0 1327-01) from the United States National Institutes of Health. Mr J Fraser thanks the Director General of Health for New Zealand for permission to publish these data.

This study was supported by a grant from the Wellington School of Medicine.

\section{References}

1. Smith AH, Pearce NE, Fisher DO, Giles HG, Teague CA, Howard JK. Soft tissue sarcoma and exposure to phenoxyherbicides and chlorophenols in New Zealand. J Natl Cancer Inst 1984;73:1111-7.

2. Smith AH, Pearce NE. Update on soft tissue sarcoma and phenoxyherbicides in New Zealand. Chemosphere 1986;15:1795-8.

3. Pearce NE, Smith AH, Howard JK, Sheppard RA, Giles HJ, Teague CA. Non-Hodgkin's lymphoma and exposure to phenoxyherbicides, chlorophenols, fencing work, and meat works employment: a case-control study. Br J Ind Med 1986;43:75-83.

4. Pearce NE, Sheppard RA, Howard JK, Fraser J, Lilley BM. Leukemia among New Zealand agricultural workers: a cancer registry based study. Am J Epidemiol 1986;124:402-9.

5. Pearce NE, Sheppard RA, Smith AH, Teague CA. NonHodgkin's lymphoma and farming: an expanded casecontrol study. Int J Cancer 1987;39:155-61.

6. Pearce NE, Smith AH, Reif JS. Increased risks of soft tissue sarcoma, malignant lymphoma, and acute myeloid leukemia in abattoir workers. Am J Ind Med 1988;14: $63-72$.

7. Johnson ES, Fischman HR, Matanoski GM, Diamond E. Cancer mortality among white males in the meat industry. J Occup Med 1986;28:23-32:

8. Johnson ES, Fischman HR, Matanoski GM, Diamond E. Occurrence of cancer in women in the meat industry. Br J Ind Med 1986;43:597-604.

9. Fox AJ, Lynge E, Malker H. Lung cancer in butchers [letter to the Editor]. Lancet 1982;1:165-6.

10. Griffith GW. Lung cancer in butchers [letter to the Editor]. Lancet 1982;1:399.

11. Lynge E, Andersen O, Kristensen TS. Lung cancer in 
Danish butchers [letter to the Editor]. Lancet 1983; 1:527-8.

12. Doerken $\mathbf{H}$, Rehpenning W. Lung cancer in butchers [letter to the Editor]. Lancet 1982;1:561.

13. Gustavsson P, Fellenius E, Hogstedt C. Possible causes of increased lung cancer incidence among butchers and slaughterhouse workers. Scand J Work Environ Health 1987;13:518-23.

14. Sen NP, Miles WF, Donaldson B, Panlakis T, Iyengar JR. Formation of nitrosamines in meat curing mixture. Nature 1973;245:104-5.

15. Ito N, Fukushima S, Hagiwara A, Shibata M, Ogiso T. Carcinogenicity by butylated hydroxyanisole in F344 rats. J Natl Cancer Inst 1983;70:343-53.

16. Miller MJ, Miller LD, Olsen C, Gillette KG. Virus-like particles in phytohemagglutinin stimulated cultures with reference to bovine lymphosarcoma. J Natl Cancer Inst 1969;43:1297-305.

17. Miller JM, VanderMaaten MJ. Infectivity tests of secretions and excretions from cattle infected with bovine leukemia virus. J Natl Cancer Inst 1979;62:425-8.

18. Foster FH. The New Zealand Cancer Registry. $\mathrm{NZ}$ Med J 1977;86:341-3.

19. Smith AH, Pearce NE, Callas PW. Cancer case-control studies with other cancers as controls. Int J Epidemiol 1989;17:298-306.

20. Pearce NE, Checkoway H. Case-control studies using other diseases as controls: problems of excluding exposure-related diseases. Am J Epidemiol 1988;127: $851-6$.

21. Department of Statistics. New Zealand standard classification of occupations. Wellington: Department of Statistics, 1980.

22. International Labour Office. International standard classification of occupations. Geneva: International Labour Office, 1968.

23. SAS Institute Inc. SAS users guide: statistics, version 5 edition. Cary, North Carolina: SAS Institute Inc, 1985.

24. Mantel N, Haenszel W. Statistical aspects of the analysis of data from retrospective studies. J Natl Cancer Inst 1959;22:719-48.

25. Miettinen OS. Estimation and estimability in case-control studies. Am J Epidemiol 1976;103:226-35.

26. Andrasch RH, Bardana EJ. Thermoactivated price-label fume intolerance: a cause of meat-wrapper's asthma. JAMA 1976;235:937.

27. Polakoff PL, Lapp L, Reger R. Polyvinyl chloride pyrolysis products. Arch Environ Health 1975;30:269-71.

28. Infante PF, Rinsky RA, Wagoner JK, Young R. Leukemia in benzene workers. Lancet 1977;2:76-8.

29. International Agency for Research on Cancer. Some industrial chemicals and dyestuffs. Lyon: International Agency for Research on Cancer, 1982;269-85. (IARC monographs on the evaluation of carcinogenic risk of chemicals to humans, vol 29).

30. Doll R, Peto R. The causes of cancer. New York, New York: Oxford University Press, 1983:1221-4.

31. Wynder EL, Covey LS, Mabuchi K, Mushinski M. Environmental factors in cancer of the larynx: a second look. Cancer 1976;38:1591-1601.

32. Department of Statistics. New Zealand census of population and dwellings 1981: bulletin on cigarette smoking. Wellington: Department of Statistics, 1983.

33. Axelson O. Aspects on confounding in occupational health epidemiology [letter to the Editor]. Scand J Work Environ Health 1978;4:98-102.

34. Glover JC, Hughes IR, Vivian GW. Mould growth on pickled pelt. J Soc Leather Technol Chem 1975;59: $74-8$.
35. National Cancer Institute. Bioassay of 2,4,6-trichlorophenol for possible carcinogenicity. Washington, DC: US Department of Health Education and Welfare, 1979. (Technical report series 155 ).

36. Hardell L, Sandstrom A. Case-control study: soft-tissue sarcomas and exposure to phenoxyacetic acids or chlorophenols. Br J Cancer 1979;39:711-7.

37. Eriksson M, Hardell L, Berg NO, Moller T, Axelson $O$. Soft tissue sarcomas and exposure to chemical substances: a case-referent study. Br J Ind Med 1981;38: $27-3$.

38. Hardell L, Eriksson M, Lenner P, Lundgren E. Malignant lymphoma and exposure to chemicals, especially organic solvents, chlorophenols and phenoxy acids: a case-control study. Br J Cancer 1981;43:169--76.

39. Sandler DP, Collman GW. Cytogenetic and environmental factors in the etiology of the acute leukemias in adults. Am J Epidemiol 1987;126:1017-32.

40. Blair A, Malker H, Cantor KP, Burmeister L, Wiklund K. Cancer among farmers: a review. Scand J Work Environ Health 1985;11:397-407.

41. Blair A, Hayes HM Jr. Mortality patterns among US veterinarians; 1947-1977: an expanded study. Int J Epidemiol 1982;11:391-7.

42. Parrish GR, Oliver RE, Weddell W, Corrin KC. Bovine leukemia virus infection in New Zealand. NZ Vet J 1981; 30:56-8.

43. Burny A, Bruck C, Chantrenne H. Bovine leukemia virus: a new mode of leukemogenesis. In: Klein G, ed. Advances in viral oncology; vol 5. New York, New York: Raven Press, 1985;35-55.

44. Piper CE, Abt DA, Ferrer JF, Marshak RR. Seroepidemiological evidence for horizontal transmission of bovine C type virus. Cancer Res 1975;35:2714-6.

45. Ferrer JF, Kenyon SJ, Gupta P. Milk of dairy cows frequently contains a leukemogenic virus. Science 1981; 213:1014-6.

46. McClure HM, Keeling ME, Custer RP, Marshak RR, Abt DA, Ferrer JF. Erythroleukemia in two infant Chimpanzees fed milk from cows naturally infected with bovine C-type virus. Cancer Res 1974;34:2745-57.

47. Van Der Maaten MJ, Miller JM. Serological evidence of transmission of bovine leukemia virus to chimpanzees. Vet Microbiol 1976;1:351-7.

48. Diglio CA, Ferrer JF. Introduction of syncytia by the bovine C type leukemia virus. Cancer Res 1976;105667.

49. Donham KJ, Van Der Maaten KJ, Miller JM, Kruse BC, Rubino MJ. Seroepidemiologic studies on the possible relationship of human and bovine leukemia: brief communication. J Natl Cancer Inst 1977;59:851-2.

50. Olsen C, Driscoll DM. Bovine leukosis: investigation of risk for man. J Am Vet Med Assoc 1978;173:1470—2.

51. Caldwell RG, Baumgartner $L$, Carter $C$, et al. Seroepidemiologic testing in man for antibodies to feline leukemia virus and bovine leukemia virus. Bibl Haematol 43:238-41, 1976.

52. Trainin Z, Meirom R, Barnes A. Common reactivity of bovine and human sera towards bovine lymphoid tumor cells. Bibl Haematol 43:232-34, 1976.

53. Copeland KT, Checkoway H, McMichael AJ, Holbrook RH. Bias due to misclassification in the estimation of relative risk. Am J Epidemiol 1977;105:486-95.

Received for publication: 15 August 1988 